\title{
Socio-demographic and Clinical Characteristics of 113 Adolescents with Bipolar Disorder: An Inpatient Sample from Turkey
}

\section{Bipolar Bozukluk Tanısı ile İzlenen 113 Ergen Hastada Sosyo-demografik ve Klinik Özellikler: Bir Yataklı Klinik Örneklemi}

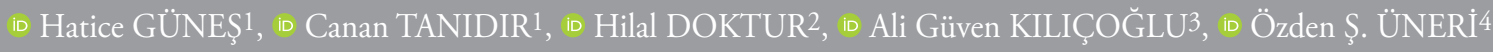

1'stanbul Gelişim University, Department of Psychology, İstanbul Turkey

${ }^{2}$ University of Health Science Bakırköy Training and Research Hospital, Mental Health and Neurological Disorders, Department of Child and

Adolescent Psychiatry, İstanbul, Turkey

33Bezmialem Vakıf University Faculty of Medicine, Department of Child and Adolescent Psychiatry, İstanbul, Turkey

${ }_{4}^{4}$ Ankara Yıldırım Beyazıt University Faculty of Medicine, Department of Child and Adolescent Psychiatry, Ankara, Turkey

\section{ABSTRACT}

Objective: Pediatric bipolar disorder (BD) is a highly morbid disorder which is associated with impairments in social, academic, and family functioning. Despite its great impact on public health, the literature is scarce regarding the studies examining the clinical phenomenology of BD in children and adolescents.

Methods: A retrospective chart review of 113 children and adolescents' files (ages 13-18 years) who were consecutively admitted to our inpatient clinic between March 2012 and November 2014 and diagnosed as having BD type I or BD type II was made. The diagnoses were based on DSM-IV-TR criteria. A sociodemographic and clinical data form was created by the authors and was filled out for each patient by the authors themselves.

Results: Totally 113 adolescents (71 male, 42 female) were included in the study. Mean age of the sample was $16.054 \pm 1.23$ (range=13-18) years. Mean age of onset of BD was $15.04 \pm 1.74$ (range=9-17) years. The first mood episode was manic in $60 \%$ of patients, depressive in $27.3 \%$, mixed in $10.9 \%$ and hypomanic in $1.8 \%$ of patients. Of the patients, $23.4 \%$ had a suicide attempt history, $48.2 \%$ had a previous referral to a psychiatry clinic before the onset of BD. History of

\section{ÖZ}

Amaç: Pediyatrik bipolar bozukluk (BB) sosyal, akademik ve aile içi işlevsellikte bozulma ile seyreden bir ruh sağlığı bozukluğudur. Toplum sağlığı açısından taşıdığı öneme karşın, literatürde çocuk ve ergenlerde BB klinik görünümlerine ilişkin araştırma sayısı göreceli olarak azdir.

Yöntemler: Bir yataklı tedavi ünitesinde BB-1 ve BB-2 tanısı ile izlenen 113 çocuk ve ergen olgunun tedavilerine ilişkin kayıtlar geriye dönük olarak taranmıştır. BB-1 ve BB-2 tanıları DSM-IVTR kriterleri temel alınarak konulmuştur. Araştırmacılar tarafından oluşturulan sosyo-demografik ve klinik veri formu, her bir olguya ait kayıtların, araştırmacılarca incelenmesi sonucunda elde edilen bilgiler doğrultusunda doldurulmuştur.

Bulgular: Çalışmaya toplamda 113 hasta (71 erkek, $42 \mathrm{kız}$ ) dahil edilmiştir. Örneklemin ortalama yaşı 16,054 1.23 (13-18) olarak

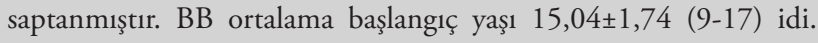
Olguların \%60'ında ilk duygudurum epizodu manik, \%27,3'ünde depresif, \%10,9'unda karma, ve \%1,8'inde hipomanikti. Olguların \%23,4'ünün öyküsünde geçmişte intihar girişimi mevcuttu. Olguların \% 48,2‘si BB başlangıcından önce bir psikiyatri kliniğine başvuruda bulunmuştu. Olguların \%27,4’ünde madde/alkol

Address for Correspondence: Hatice GÜNEŞ, İstanbul Gelişim University, Department of Psychology, İstanbul, Turkey

Phone: +90 5057266083 E-mail: dr_haticegunes@yahoo.com ORCID ID: orcid.org/0000-0003-4840-1770

Cite this article as: Güneş H, Tanıdır C, Doktur H, Kılıçoğlu AG, Üneri Öş. Socio-demographic and Clinical Characteristics of 113 Adolescents with Bipolar Disorder: An Inpatient Sample from Turkey. Bezmialem Science 2020;8(2):125-32. 
substance/alcohol use was present in $27.4 \%$ of the patients. Of the patients, $84.9 \%$ were using combination treatments.

Conclusion: High rates of suicide attempt, substance use and significant functional impairment found in our study sample indicate that early recognition and intervention of $\mathrm{BD}$, specialized educational programs and occupational support for these children and adolescents seem indispensable.

Keywords: Bipolar disorder, adolescent, inpatient, clinical characteristics kullanımı mevcuttu. Olguların \%84,9'unda çoklu ilaç tedavisi kullanılmıştı.

Sonuç: İntihar girişimi, madde kullanımı ve işlevsellikte önemli ölçüde bozulma sıklığı BB'de erken tanı ve tedavinin, özel eğitim programlarının ve mesleki desteğin, bu tanıyı alan çocuk ve ergenler için öneminin büyüklüğünün altını çizmektedir.

Anahtar Sözcükler: Bipolar bozukluk, ergen, yataklı tedavi, klinik özellikler

\section{Introduction}

Bipolar disorder (BD) is a highly morbid disorder increasingly recognized in adolescents (1). The overall rate of $\mathrm{BD}$ was reported to be $1.8 \%$ in a meta-analysis of epidemiologic studies of pediatric BD including participants between the ages of 7 and 21 years (2). Several studies have supported a strong genetic component in pediatric patients and early onset $\mathrm{BD}$; and family studies have found a high rate of BD particularly among the relatives of individuals with pediatric BD (3-7). Age at onset has been defined as a clinical marker that may indicate more homogenous, neurobiologically distinctive subgroups (8). Pediatric BD is associated with high rates of repeated hospitalizations and suicide attempts and impairments in social, academic, and family functioning (5,9-13). Furthermore, significant associations were found between pediatric $\mathrm{BD}$ and substance use disorders (SUDs) in several studies $(8,10,14-$ 19). In a study including 502 outpatients with BD, Holtzman et al. reported that 328 of those with childhood or adolescentonset $\mathrm{BD}$ had significantly higher rates of unfavorable illness characteristics, lifetime alcohol use disorder, and prior suicide attempt, than those with adult-onset BD (8).

Despite the high rate of the disorder and its public health significance, there are relatively few published studies examining the clinical phenomenology of $\mathrm{BD}$ in children and adolescents in Turkey. To our knowledge, there are only two epidemiologic studies of BD in Turkish children. Both studies were conducted in prepubertal community samples. Diler et al. (20) screened 2468 (1.176 girls; 1.292 boys) randomly selected elementary school students aged between 7 and 11 years by using the ParentYoung Mania Rating scale (P-YMRS). In the study, 19 (59.4\%) boys and $13(40.6 \%)$ girls had mania (mean age $=9.31 \pm 1.47)$. In the mania group, being talkative/pressured speech, increased motor activity (high energy), elevated mood, sleep problems, rapid thoughts / flight of ideas, and irritability were the symptoms with the highest mean P-YMRS scores. In a recent epidemiologic study, Karacetin et al. screened affective disorders in $5842(51.5 \%$ male; mean age $8.7 \pm 1.2)$, elementary school students between second and fourth grades by using the Kiddie Schedule for Affective Disorders and Schizophrenia for School Age Children- Present and Lifetime Version (K-SADS-PL) as a part of the "The Epidemiology of Childhood Psychopathology in Turkey" (EPICPAT-T) study (21). In this study, the reported prevalence rate of affective disorders was $2.5 \%$ without taking into account impairment and $1.6 \%$ when impairment was considered. However, unlike the study by Diler et al. (20), none of the participants in this research diagnosed with $\mathrm{BD}$.

In a study from Turkey, Erkıran et al. (22) aimed to determine the relationship between age at onset and phenomenology of BD. Socio-demographic and clinical features, type of episode, number and duration of hospitalizations were compared between the groups consisted of adolescent-onset adolescents $(n=60)$, adolescent-onset adults $(n=60)$ and adult-onset adults $(n=60)$. The authors concluded that adolescent-onset BD was associated with higher probability of mixed episodes, psychotic features including mood congruent or incongruent hallucinations and delusions. A case series of children and adolescents with $\mathrm{BD}$ aged between 7 and 15 years was reported by Inal Emiroğlu (23). In this case series, 7 (3 girls, 4 boys) children and adolescents with BD were assessed by Washington University in St. Louis Kiddie Schedule for Affective Disorders and Schizophrenia, Lifetime and Present Episode Version, DSM-IV (WASH-U-KSADS). The authors reported that grandiosity, distractibility and abnormal energy were the most frequently detected symptoms. In this case series, 4 patients had mixed cycling features, 5 had ultradian cycling and 1 had rapid cycling (23).

In another study, Diler et al. (24) aimed to differentiate Turkish children with attention deficit hyperactivity disorder (ADHD) from those with comorbid ADHD and $\mathrm{BD}$ and compare the clinical features of the groups. In their study, they evaluated 147 treatment- and drug-naive children (123 boys, 24 girls), aged between 7 and 13 years, who had been consecutively admitted to the ADHD clinic. In the group studied, 12 children $(8.2 \%$; 12 boys) had comorbid bipolar disorder (ADHD + BD). In comparison with the ADHD group, the $\mathrm{ADHD}+\mathrm{BD}$ group had increased rates of depressive disorders, oppositional defiant disorder (ODD), panic disorder and a family history of $\mathrm{BD}$. The onset of manic episodes in the $\mathrm{ADHD}+\mathrm{BD}$ group was $9.24 \pm 0.68$ years of age. Seven cases $(58.3 \%)$ in the ADHD + BD group had bipolar disorder not otherwise specified (BD-NOS). Of the patients with BD-NOS, $57.1 \%$ had rapid-cycling episodes. Four patients $(33.3 \%)$ had BD type I with mixed episodes $(75 \%$ of them were rapid-cycling), 1 (8.3\%) patient with $\mathrm{BD}$ type I had manic episodes. Seven patients (58.3\%) in both groups had rapid cycling episodes. None of the patients with ADHD + BD had psychotic symptoms (24). In a similar study, Lus and Motavalli Mukaddes (25) evaluated the comorbidity of BD in 121 individuals, aged 6-16 years (23 girls; 98 boys), with a diagnosis of ADHD. A comorbid diagnosis of $\mathrm{BD}(\mathrm{ADHD}+\mathrm{BD})$ was 
identified in 10 children (8.3\%; 8 boys, 2 girls). The age of onset of $\mathrm{BD}$ in $\mathrm{ADHD}+\mathrm{BD}$ group ranged between 7 and 12 years (mean age $=8.9 \pm 2.2$ years). Two patients $(20 \%)$ in the ADHD + BD group had BD type II and 8 patients (80\%) had BPD type I, of whom 2 had rapid cycling episodes and 1 of them had rapid cycling episodes with psychotic features (25).

In a naturalistic and prospective study, Inal Emiroğlu et al. (26) aimed to describe the clinical manifestation and predictors of response to treatment in Turkish children and adolescents with BD. The study included 27 consecutive referrals to a child and adolescent psychiatry clinic. The mean age of the study group was $12.95 \pm 3.8$ years. The results of the study showed that mood stabilizers and atypical antipsychotic combinations were required in many cases $(73.7 \%)$. Most of the patients responded to mood stabilizers and antipsychotic agents (89.5\%). In this study, episodic patients mostly consisted of adolescent cases were more likely to have psychotic features and to have a later age of onset compared to the non-episodic group (26). Ertan and Cetinkaya (27) conducted a retrospective chart review of 47 patients (mean age $=19.2 \pm 1.7 ; 31$ female, 16 male) consecutively admitted to an adolescent outpatient clinic and diagnosed as having BD (27). Of the patients, $38.3 \%$ (18) were admitted with mania/hypomania symptoms first, and $23.4 \%$ (11) of the patients were admitted with depressive symptoms. The mean duration between the first occurrence of the symptoms and the diagnosis was $1 \pm 1.6$ years. Of the participants, $25.5 \%$ (12) committed suicide and $12.8 \%$ had self-injurious behavior. Of the patients, $59.6 \%$ had at least one comorbid disorder. The most detected comorbid disorders were ADHD (21.3\%), intellectual disability (14.9\%), and obsessive compulsive disorder (10.6\%) respectively. Of the cases, $87.2 \%$ were using mood stabilizers, $93.6 \%$ were using antipsychotic agents and $19.1 \%$ were using antidepressants. Lithium $(38.2 \%$, $\mathrm{n}=18$ ) was the most frequently prescribed mood stabilizer in the study group which was followed by valproic acid $(29.7 \%, \mathrm{n}=14)$ and lamotrigine $(23.4 \%, \mathrm{n}=11)$ respectively. The most frequently prescribed antipsychotics were olanzapine $(27.6 \%, \mathrm{n}=13)$, risperidone $(27.6 \%, \mathrm{n}=13)$ and aripiprazole $(21.2 \%, \mathrm{n}=10)$. Sertraline $(4.2 \%, \mathrm{n}=2)$, fluoxetine $(4.2 \%, \mathrm{n}=2)$ and venlafaxine $(4.2 \%, n=2)$ were the most frequently used antidepressants. Of the patients, $6,4 \%$ used psychostimulants; and atomoxetine was used in 2 patients $(4.2 \%)$. Of the patients, $19.2 \%(\mathrm{n}=9)$ were treated with monotherapy; $44.7 \%(\mathrm{n}=21)$ with 2 ; and $36.1 \%(\mathrm{n}=17)$ with 3 or more psychotropic agents (27). Although main aim of the researchers was to define the clinical and neuropsychological characteristics of $\mathrm{BD}$ in adolescents and to evaluate the clinical and neuropsychological variables in adolescents with a higher familial risk of $\mathrm{BD}$, and to identify probable early markers of the disorder; Karakurt et al. (28) reported clinical features of 25 patients with BD (aged 12-18 years). Of those, 12 (48\%) had BD type I, $10(40 \%)$ BD type II and $3(12 \%)$ BD-NOS. In their study group, the mean age of onset was $12 \pm 2.7$ years; mean age at diagnosis was $13.7 \pm 2.0$ years; mean number of depressive episodes and mania/hypomania episodes was $1.3 \pm 0.9$ and $1.4 \pm 0.9$, respectively. Of the patients, $22(88 \%)$ were using mood stabilizers, $4(16 \%)$ were using antidepressants and 3 $(12 \%)$ were using stimulants. The number of the cases using multiple psychotropic agents was $22(88 \%)$. The most detected comorbid disorder were ADHD (56\%, $\mathrm{n}=14)$, anxiety disorders $(28 \%, \mathrm{n}=7)$ and conduct disorders $(24 \%, \mathrm{n}=6)(28)$.

As summarized above, there are a few studies from Turkey presenting sociodemographic data, clinical presentation and treatment regimens of child and adolescent patients with $\mathrm{BD}$ and the total number of the child and adolescent patients reported in these studies is still limited. In this study, we aimed to examine the clinical characteristics and family history of children and adolescents with $\mathrm{BD}$ having treatment in an inpatient unit. We hypothesized that the family history of $\mathrm{BD}$, history of suicide attempts and substance use; and functional impairment would be high in this sample.

\section{Methods}

A retrospective chart review of 113 children and adolescents' files (ages 13-18 years) who were consecutively admitted to our inpatient clinic between March 2012 and November 2014 and diagnosed as having $\mathrm{BD}$ type I or $\mathrm{BD}$ type II was made. The diagnoses were based on the DSM-IV-TR (29) criteria and made by the child and adolescent psychiatrists who were experienced in the field at least for ten years.

A sociodemographic and clinical data form was created by the authors and filled out for each patient by the authors themselves. Data were obtained from the patients' files. The data form covered the current age and education status of the patient, employment status, age at onset of $\mathrm{BD}$, type of the first and the current episode, history of suicide attempt, history of substance/ alcohol use, previous referral to a psychiatry clinic before the onset of $\mathrm{BD}$, family history for $\mathrm{BD}$ or any psychiatric disorder and treatment regimens during the inpatient stay.

\section{Statistical Analysis}

SPSS (Statistical Package for the Social Sciences), version 16.0 (SPSS, Inc., Chicago, IL) was used for analyzing the data obtained in this study. Descriptive analyses were utilized for sample description: frequencies and percentages for discrete variables and means and standard errors for continuous variables. Categorical variables were compared with two tailed $\mathrm{X}^{2}$ test (Fisher's test). Statistical significance was defined by a probability level of $\mathrm{p}<0.05$.

\section{Results}

Totally 113 (71 male, 42 female) adolescents were included in the study. Mean age of the study group was $16.054 \pm 1.23$ (range $=13-18$ ) years. There was no statistically significant difference between male and female subjects regarding onset age of BD (females: mean age at onset 14.94 1.9 ; males: mean age at onset $15.1 \pm 1.6, p>0.05)$, regarding substance use history and history of BD in the family ( $>0.05)$. However, suicide attempt rates were higher in female subjects (58\%) compared to male subjects $(32 \%)(\mathrm{p}=0.02)$. During the time of assessment, 39 adolescents (34.5\%) were attending a high school, 12 (10.6\%) had a regular job, $62(54.9 \%)$ were not attending any school 
or did not have a regular job. Mean education year for the whole group was 8.2 years. There was no difference between the subjects not attending any school or not having a regular job and the rest of the study group with regards to the age at onset of $\mathrm{BD}$, history of $\mathrm{BD}$ in the family and substance use history ( $>0.05$ ).

Mean age at onset of BD was $15.04 \pm 1.74$ (range $=9-17$ ) years. In $50 \%$ of the study group the age at onset of BD was less then age of 15 years and in $15.4 \%$, it was less than age of 13 years. There was no statistically significant difference between childhood onset ( $\leq 13$ years) and adolescent onset ( $>13$ years) cases regarding occupational functioning (attending school or having a regular job), suicide attempt history, substance use history, and history of $\mathrm{BD}$ in the family ( $\mathrm{p}>0.05)$.

Of the patients, $92.5 \%$ had a diagnosis of BD type I, and $7.5 \%$ had BD type II. The first mood episode was manic in $60 \%$ of patients, depressive in $27.3 \%$, mixed in $10.9 \%$ and hypomanic in $1.8 \%$ of the patients. Of the patients, $32.1 \%$ had a positive family history for BD. In $56.6 \%$, a history of any psychiatric disorder was reported in the first-degree relatives. Of the patients, $23.4 \%$ had a suicide attempt history, $48.2 \%$ had a previous referral to a psychiatry clinic before the onset of BD. History of substance/alcohol use was detected in $27.4 \%$ of the patients. Types of the first and the current mood episodes of the patients are shown in Table 1.

Eighty nine (78.7\%) patients were using "atypical antipsychotic + mood stabilizer" combination (55 patients: Atypical antipsychotic + valproate; 30 patients: Atypical antipsychotic + lithium; 4 patients: Atypical antipsychotic + carbamazepine), $16(14.1 \%)$ patients were using only atypical antipsychotics; $2(1.7 \%)$ patients were using "atypical antipsychotic + typical antipsychotic" combination (haloperidol), 4 (3.5\%) patients were using "mood stabilizer + mood stabilizer" combination (1 patient, valproate + lithium; 2 patients, lithium + carbamazepine, 1 patient, lithium + topiramate), 1 patient was using only valproate and 1 patient was using "lithium + antidepressant" combination.

\section{Discussion}

In this study, we found high rates of family history of $\mathrm{BD}$, suicide attempt history and substance use history in an adolescent inpatient sample with BD. Functional impairment was striking given that more than half of the patients were not attending any school or did not have a regular job. This was compatible with the literature strongly suggesting that

Table 1. Types of the first and the current mood episodes

First mood episode Current mood episode

\begin{tabular}{l|l|l|l|l}
\hline & $\mathrm{N}$ & $\%$ & $\mathrm{n}$ & $\%$ \\
\hline Manic & 66 & 60 & 82 & 73.2 \\
\hline Depressive & 30 & 27.3 & 6 & 5.4 \\
Mixed & 12 & 10.9 & 22 & 19.6 \\
Hypomanic & 2 & 1.8 & 2 & 1.8 \\
\hline
\end{tabular}

pediatric $\mathrm{BD}$ was associated with chronic functional impairment (30-32). According to DelBello and colleagues' study, 85\% of adolescents with BD had syndromic recovery during the first year after initial inward treatment, whereas 39\% had symptomatic recovery and 39\% had functional recovery (32). Only $20 \%$ experienced all three types of recovery. Goldstein et al. (33) also reported mild to moderate psychosocial functional impairment in work (including academics) and interpersonal domains in children and adolescents with $\mathrm{BD}$. When patients with greater occupational impairment (not having a regular job or not attending any school) were compared with the rest of the study group, we found no difference with regards to onset age or family history of $\mathrm{BD}$. In line with our finding, the literature suggests that childhood or adolescent onset $\mathrm{BD}$ both cause significant functional impairment, although inconsistencies exist $(26,31,33)$. To the best of our knowledge, this was the first study to examine the link between familiality and the severity of functional impairment in pediatric BD. However, in line with our findings, Sanchez-Moreno et al. (34) reported no significant relationship between a history of affective disorders in the family and low functioning in adults with $\mathrm{BD}$.

The number of male patients was higher than the female patients in our study. Although bipolar disorder affects both males and females equally, patients with early-onset disorder, particularly cases with an onset before 13 years of age are reported to be predominantly male (35). In this study, female and male subjects did not show any difference with regards to onset age of $\mathrm{BD}$, substance use history and family history of bipolar disorder. However, suicide attempt rates were higher in female subjects. Previous researches indicated that pediatric BD showed similarities regarding most clinical features between the sexes (36-38) with exception that there was a later age at onset in female subjects $(37,38)$. Subject ascertainment differences and older mean age in our study sample might be responsible for this discrepancy. Along with our results, one of two comprehensive reviews on suicidality in $\mathrm{BD}$ suggested that female genderwas a possible risk factor for suicide attempts in youth with $\mathrm{BD}$, however, this finding was not consistent $(39,40)$.

Most of our patients had BD-1 diagnosis and the current mood episode was manic in most of the group which was an expected finding considering that our study sample consisted of patients having treatment in an inpatient clinic. These two findings might be the result of referral bias, that is, patients with disruptive behaviors are identified easily and probably more referred for treatment in an inpatient unit.

In this study, the first mood episode was manic in more than half of the patients. This finding seemed to be in contradiction with the study including 1081 patients diagnosed as having BD, which reported that the majority of first episodes (58.9\%) were depressive (41). But the estimated onset age was reported as $28.5 \pm 12.4$ years in that study which was older than our sample's onset age. Our study sample consisted of individuals from lower socioeconomic level, therefore a depressive episode may have been easily overlooked by the parents who had many challenges 
in life. However, in a study including 82 juveniles with BD, most of whom were prepubertal at illness-onset, the first episode was reported as manic in $52.4 \%$, mixed in $30.5 \%$, and depressive in $17.1 \%$ of cases (42). In a study from Turkey, similarly, the most frequent first episode was reported to be manic in an inpatient sample of adolescents with $\mathrm{BD}$ although the rates $(38.3 \%)$ were smaller than those found in our study (27).

Nearly half of the cases had a history of previous psychiatric referral before the onset of $\mathrm{BD}$. This finding may be consistent with the data that $\mathrm{BD}$ is a highly comorbid disorder $(12,43)$ or this may be the result of the developmental differences in the expression of manic symptoms of this disorder in children. In addition, premorbid mental problems have been reported to be frequent in early-onset $\mathrm{BD}$, particularly disruptive behavior disorders, irritability, and behavioral dyscontrol (35,44-46). Moreover, Ertan and Çetinkaya (27) reported a comorbidity rate of 59.6\% in their adolescent inpatient sample which was also compatible with our study. Karakurt et al. (28) also reported increased rates of ADHD and generalized anxiety disorder in their study group of adolescents with $\mathrm{BD}$ compared to adolescents with $\mathrm{BD}$ in a first-degree relative.

Suicide is a serious problem for patients with BD. Suicide attempt rates range from $25 \%$ to $56 \%$, and completed suicides range from $10 \%$ to $15 \%$ (47). Significant relations were reported especially between early-onset $\mathrm{BD}$ and lifetime suicide attempts in many studies $(5,10-12)$. Nearly a quarter of our patients had a history of suicide attempt. This finding was compatible with a comprehensive review of $\mathrm{BD}$, which reported that $31.1 \%$ of the individuals with $\mathrm{BD}$ attempted suicide at least once (48). In addition, Ertan and Çetinkaya (27) also reported similar rates $(25.5 \%)$ of suicide attempts in another Turkish adolescent inpatient sample with $\mathrm{BD}$. In line with the previous literature (49), we also found that the suicide attempt ranges were significantly higher in the patients with a family history of $\mathrm{BD}$ (37\%) compared with the ones who did not have a family history of $\mathrm{BD}(17 \%)(\mathrm{p}=0.03)$.

Nearly one-third of our patients had used alcohol or illicit drugs at a point in their lives. There is a substantial body of evidence demonstrating a greater risk of substance use in youth with $\mathrm{BD}$, with a prevalence rate ranging between $16 \%$ and $39 \%(50,51)$. The nature of the relationship between BD and SUD seems bidirectional. Besides genetic vulnerabilities, adolescents with $\mathrm{BD}$ may be inclined to self-medicate themselves due to the associated features of pediatric BD such as affective instability, behavioral disinhibition, high impulsivity, sensation seeking, cognitive impairment, and deficient self-regulation (52). Substance use in adolescents with $\mathrm{BD}$ is associated with higher rates of legal problems, suicidality, psychiatric comorbidity and physical or sexual abuse (50-54). Thus, one might hypothesize that substance use might contribute to the poorer academic and occupational functioning in adolescents with BD. Conversely, in our analysis, the patients without a regular job and who did not attend school did not differ from the others with regards to substance use history.
In more than half of the patients there was a psychiatric disorder history in the first-degree relatives, and in more than one-third there was BD history including all relatives. In the literature on adults with $\mathrm{BD}$; twin, adoption, and family history studies supported a significant genetic vulnerability, with a four to six-fold raised risk for BD in first degree relatives of affected individuals (55). The degree of familiality seemed to be greater in early-onset cases (6). Since psychopathology in parents may be regarded as an early-life stressor as well as a marker of a genetic vulnerability to mental health problems, the raised risk of bipolar disorder in the offspring is not surprising, given that psychiatric symptoms in parents might impact family functioning and lead to a less cohesive environment, which renders offspring liable to the development of psychopathology (7).

In $50 \%$ of the participants in our study, the onset age of $\mathrm{BD}$ was less than age of 15 years and in $15.4 \%$ it was less than age of 13 years. Suicide attempt history, substance use history and history of $\mathrm{BD}$ in the family did not differ between childhood and adolescent onset subjects. A comprehensive review of suicidality in pediatric $\mathrm{BD}$ implied that adolescent onset $\mathrm{BD}$ might be related with a greater risk of suicide attempts, however this was not a consistent finding $(40,56)$. Considering that our study group consisted of inpatient cases with a possibility of greater severity, that might be related to a lack of difference in suicide attempt risk across onset age groups. Propper et al. (56) reported that very early onset subjects were more likely to have a firstdegree relative with an affective disorder and they showed lower global functioning compared with early onset subjects. However, in the study by Propper et al. (56), the age cut off between very early and early onset subjects were older (age cut off $=15$ years) and their study sample consisted of only adult subjects. Literature provided controversial results on whether the prevalence rate of substance use differed between childhood or adolescent onset $\mathrm{BD}$. Wilens et al. reported higher risk for substance use in adolescent onset $\mathrm{BD}$ in an ongoing, controlled, family-based study $(54,57)$, whereas Goldstein et al. (53) presented similar results with our study. Retrospective data from adults with $\mathrm{BD}$ also indicated that early onset $\mathrm{BD}$ was associated with greater risk for substance use, but childhood onset and adolescent onset BD appeared to confer similar vulnerability to substance use (58).

In our study, most of the patients were using atypical antipsychotic + mood stabilizer combination. Sodium valproate was the most frequently prescribed mood stabilizer in this combination. To date, lithium, risperidone, olanzapine, aripiprazole and quetiapine were approved by the Food and Drug Administration (FDA) for the treatment of acute mixed and manic episodes in pediatric $\mathrm{BD}$. Second generation antipsychotics are reported to be more effective than mood stabilizers for the treatment of manic episodes in pediatric bipolar disorder. There is some evidence in the literature suggesting that divalproex might be effective in the treatment of acute manic episodes in pediatric $\mathrm{BD}$, however current data on divalproex use in pediatric $\mathrm{BD}$ are quite limited $(59,60)$. The only medication that is currently approved for the treatment of depressive episodes in pediatric $\mathrm{BD}$ is olanzapine/ fluoxetine combination (60). Although current data on whether 
combination therapy is more effective than monotherapy in pediatric bipolar disorder remain scarce, antipsychotic + mood stabilizer combination might be an alternative treatment for the patients resistant to mood stabilizer monotherapy (60). Our sample was collected from an inpatient unit which might be related with a more severe course of illness, thus led to a greater likelihood for the use of combination treatment. Similarly, studies with inpatient adolescent samples from Turkey also reported higher rates of combination therapies $(80.8 \%$ and $88 \%$, respectively) $(26,28)$.

Our study had some limitations which should be taken into account. Since our clinic served sometimes as a tertiary clinic, and most of our patients had a low socio-economic background, our sample may have represented a more severely impaired group. This may have contributed to our findings of high rate of family history of psychiatric disorders, substance and alcohol use and combination therapies, and low rate of school attendance or having regular job. Secondly, age at onset of BD was retrospectively determined, therefore inaccuracies in recall could not be precluded. Third, the sample consisted of inpatients who probably had more severe illness, so it was difficult to generalize these results for all children and adolescents with BD in Turkey. However, a considerable number of patients were included in this study and there were few studies in the literature from Turkey including inpatient youths with BD.

\section{Conclusion}

Our results are generally consistent with the literature that earlyonset $\mathrm{BD}$ cases have high rates of family history of $\mathrm{BD}$, suicide attempts and substance use and exhibit chronic impairments in functioning. The similarity of our results with the results of those from Western countries can be interpreted as there seems no significant cultural differences regarding clinical characteristics of $\mathrm{BD}$. High rates of suicide attempt, substance use and significant functional impairment found in our study sample indicate that early recognition and intervention of $\mathrm{BD}$, specialized educational programs and occupational support for these children and adolescents seem indispensable.

\section{Ethics}

Ethics Committee Approval: Retrospective study.

Informed Consent: Retrospective study.

Peer-review: Externally peer reviewed.

\section{Authorship Contributions}

Concept: H.G., C.T., H.D., Ö.ş.Ü., Design: H.G., C.T., H.D., Ö.Ş.Ü., Data Collection or Processing: H.G., C.T., H.D., A.G.K., Analysis or Interpretation: H.G., C.T., Writing: H.G., C.T., H.D., A.G.K., Ö.Ş.Ü.

Conflict of Interest: No conflict of interest was declared by the authors.

Financial Disclosure: The authors declared that this study received no financial support.

\section{References}

1. Wilens TE, Biederman J, Martelon M, Zulauf C, Anderson JP, Carrellas NW, et al. Further Evidence for Smoking and Substance Use Disorders in Youth with Bipolar Disorder and Comorbid Conduct Disorder. J Clin Psychiatry 2016;77:1420-27.

2. Van Meter AR, Moreira AL, Youngstrom EA. Meta-analysis of epidemiologic studies of pediatric bipolar disorder. J Clin Psychiatry 2011;72:1250-56.

3. Baldessarini RJ, Tondo L, Vazquez GH, Undurraga J, Bolzani L, Yildiz A, et al. Age at onset versus family history and clinical outcomes in 1,665 international bipolar-I disorder patients. World Psychiatry 2012;11:40-6.

4. Benazzi F. Classifying mood disorders by age-at-onset instead of polarity. Prog Neuropsychopharmacol Biol Psychiatry 2009;33:8693.

5. Ortiz A, Bradler K, Slaney C, Garnham J, Ruzickova M, O’Donovan $\mathrm{C}$, et al. An admixture analysis of the age at index episodes in bipolar disorder. Psychiatry Res 2011;188:34-9.

6. Faraone SV, Glatt SJ, Tsuang MT. The genetics of pediatriconset bipolar disorder. Biol Psychiatry 2003;53:970-77.

7. Bergink $\mathrm{V}$, Larsen JT, Hillegers $\mathrm{MH}$, Dahl SK, Stevens H, Mortensen PB, et al. Childhood adverse life events and parental psychopathology as risk factors for bipolar disorder. Transl Psychiatry 2016;6:e929.

8. Holtzman JN, Miller S, Hooshmand F, Wang PW, Chang KD, Hill SJ, et al. Childhood-compared to adolescent onset bipolar disorder has more statistically significant clinical correlates. J Affect Disord 2015;179:114-20.

9. Weinstein SM, West AE, Pavuluri M Psychosocial intervention for pediatric bipolar disorder: current and future directions. Expert Rev Neurother. 2013;13:843-50.

10. Azorin JM, Bellivier F, Kaladjian A, Adida M, Belzeaux R, Fakra E, et al. Characteristics and profiles of bipolar I patients according to age-at-onset: findings from an admixture analysis J Affect Disord. 2013;150:993-1000.

11. Coryell W, Fiedorowicz J, Leon AC, Endicott J, Keller MB. Age of onset and the prospectively observed course of illness in bipolar disorder. J Affect Disord 2013;146:34-8.

12. Moor S, Crowe M, Luty S, Carter J, Joyce PR. Effects of comorbidity and early age of onset in young people with Bipolar Disorder on self-harming behavior and suicide attempts. J Affect Disord 2012;136:1212-15.

13. Goldstein TR, Birmaher B, Axelson D, Goldstein BI, Gill MK, Esposito-Smythers C, et al. Psychosocial functioning among bipolar youth. J Affect Disord 2009;114:174-83.

14. Carter TD, Mundo E, Parikh SV, Kennedy JL. Early age at onset as a risk factor for poor outcome of bipolar disorder. J Psychiatr Res 2003;37:297-303.

15. Ernst CL, Goldberg JF. Clinical features related to age at onset in bipolar disorder. J Affect Disord 2004;82:21-7.

16. Etain B, Lajnef M, Bellivier F, Mathieu F, Raust A, Cochet B, et al. Clinical expression of bipolar disorder type $\mathrm{I}$ as a function of age and polarity at onset: convergent findings in samples from France and the United States. J Clin Psychiatry 2012;73:e561-566. 
17. Javaid N, Kennedy JL, De Luca V. Ethnicity and age at onset in bipolar spectrum disorders. CNS Spectr 2011;16:127-34.

18. Lin PI, McInnis MG, Potash JB, Willour V, MacKinnon DF, DePaulo JR, Zandi PP. Clinical correlates and familial aggregation of age at onset in bipolar disorder. Am J Psychiatry 2006;163:240-46.

19. Rende R, Birmaher B, Axelson D, Strober M, Gill MK, Valeri S, et al. Childhood-onset bipolar disorder: Evidence for increased familial loading of psychiatric illness. J Am Acad Child Adolesc Psychiatry 2007;46:197-204.

20. Diler RS, Uguz S, Seydaoglu G, Avci A. Mania profile in a community sample of prepubertal children in Turkey. Bipolar Disord 2008;10:546-53.

21. Karacetin G, Arman AR, Fis NP, Demirci E, Ozmen S, Hesapcioglu ST, et al. Prevalence of Childhood Affective disorders in Turkey: An epidemiological study. J Affect Disord 2018;238:513-21.

22. Erkiran M, Karamustafalioğlu N, Tomruk N, Kahraman E, Alpay N. Phenomenological differences between adolescent and adult onset mania: a comparative study. Turk Psikiyatri Derg 2003;14:21-30.

23. Inal Emiroğlu FN. Case series with childhood bipolar disorder phenotype features. Turk Psikiyatri Derg 2004;15:148-54.

24. Diler RS, Uguz S, Seydaoglu G, Erol N, Avci A. Differentiating bipolar disorder in Turkish prepubertal children with attentiondeficit hyperactivity disorder. Bipolar Disord 2007;9:243-51.

25. Lus G, Motavalli Mukaddes N. Co-morbidity of bipolar disorder in children and adolescents with attention deficit/hyperactivity disorder (ADHD) in an outpatient Turkish sample. World J Biol Psychiatry 2009; 10:488-94.

26. Inal Emiroglu FN, Baykara B, Miral S. A case series of Turkish children and adolescents with bipolar spectrum disorder: a naturalistic clinical phenomenological follow-up. Minerva Pediatr 2008;60:51-7.

27. Ertan EA, Çetinkaya BÖ. Bipolar Disorder in Adolescents: Treatment Strategies and Comorbidities. Kriz Dergisi 2018;26.

28. Karakurt MN, Karabekiroğllu MZ, Yüce M, Baykal S, Şenses A. Neuropsychological profiles of adolescents with bipolar disorder and adolescents with a high risk of bipolar disorder. Turk Psikiyatri Derg 2013;24:221-30.

29. American Psychiatric Association. DSM-IV. Diagnostic and Statistical Manual of Mental Disorders 4th edition, TR. Washington, DC: American Psychiatric Association; 2000.

30. Wilens TE, Biederman J, Forkner P, Ditterline J, Morris M, Moore $\mathrm{H}$, et al. Patterns of comorbidity and dysfunction in clinically referred preschool and school-age children with bipolar disorder. J Child Adolesc Psychopharmacol 2003;13:495-505.

31. Biederman J, Faraone SV, Wozniak J, Mick E, Kwon A, Cayton GA, et al. Clinical correlates of bipolar disorder in a large, referred sample of children and adolescents. J Psychiatr Res 2005;39:611-22.

32. DelBello MP, Hanseman D, Adler CM, Fleck DE, Strakowski SM. Twelve-month outcome of adolescents with bipolar disorder following first hospitalization for a manic or mixed episode. Am J Psychiatry 2007;164:582-90.

33. Goldstein TR1, Birmaher B, Axelson D, Goldstein BI, Gill MK, Esposito-Smythers C, et al. Psychosocial functioning among bipolar youth. J Affect Disord 2009;114:174-83.
34. Sanchez-Moreno J, Bonnin CM, González-Pinto A, Amann BL, Solé B, Balanzá-Martinez V, et al. Factors associated with poor functional outcome in bipolar disorder: sociodemographic, clinical, and neurocognitive variables. Acta Psychiatr Scand 2018;138:145-54.

35. McClellan J, Kowatch R, Findling RL; Work Group on Quality Issues. Practice parameter for the assessment and treatment of children and adolescents with bipolar disorder. J Am Acad Child Adolesc Psychiatry 2007;46:107-25.

36. Geller B, Zimerman B, Williams M, Bolhofner K, Craney JL, Delbello MP, et al. Diagnostic characteristics of 93 cases of a prepubertal and early adolescent bipolar disorder phenotype by gender, puberty and comorbid attention deficit hyperactivity disorder. J Child Adolesc Psychopharmacol 2000;10:157-64.

37. Biederman J, Kwon A, Wozniak J, Mick E, Markowitz S, Fazio V, et al. Absence of gender differences in pediatric bipolar disorder: findings from a large sample of referred youth. J Affect Disord 2004;83:207-14.

38. Wozniak J, Biederman J, Martelon MK, Hernandez M, Woodworth KY, Faraone SV. Does sex moderate the clinical correlates of pediatric bipolar-I disorder? Results from a large controlled family-genetic study. J Affect Disord 2013;149:269-76.

39. Schaffer A, Isometsä ET, Azorin JM, Cassidy F, Goldstein T, Rihmer $\mathrm{Z}$, et al. A review of factors associated with greater likelihood of suicide attempts and suicide deaths in bipolar disorder: Part II of a report of the International Society for Bipolar Disorders Task Force on Suicide in Bipolar Disorder. Aust N Z J Psychiatry 2015;49:100620.

40. Halfon N, Labelle R, Cohen D, Guilé JM, Breton JJ. Juvenile bipolar disorder and suicidality: a review of the last 10 years of literature. Eur Child Adolesc Psychiatry 2013;22:139-51.

41. Baldessarini RJ, Tondo L, Visioli C. First-episode types in bipolar disorder: predictive associations with later illness. Acta Psychiatr Scand 2014;129:383-92.

42. Faedda GL, Baldessarini RJ, Glovinsky IP, Austin NB. Pediatric bipolar disorder: phenomenology and course of illness. Bipolar Disord 2004;6:305-13.

43. Leverich GS, Post RM, Keck PE Jr, Altshuler LL, Frye MA, Kupka RW, et al. The poor prognosis of childhood-onset bipolar disorder. J Pediatr 2007;150:485-90.

44. Geller B, Zimerman B, Williams M, Delbello MP, Bolhofner $\mathrm{K}$, Craney JL, et al. DSM-IV mania symptoms in a prepubertal and early adolescent bipolar disorder phenotype compared to attention-deficit hyperactive and normal controls. J Child Adolesc Psychopharmacol 2002;12:11-25.

45. Fergus EL, Miller RB, Luckenbaugh DA, Leverich GS, Findling $\mathrm{RL}$, Speer AM, et al. Is there progression from irritability/dyscontrol to major depressive and manic symptoms? A retrospective community survey of parents of bipolar children. J Affect Disord 2003;77:71-8.

46. McClellan J, Breiger D, McCurry C, Hlastala SA. Premorbid functioning in early-onset psychotic disorders. J Am Acad Child Adolesc Psychiatry 2003;42:666-72.

47. Carrà G, Bartoli F, Crocamo C, Brady KT, Clerici M. Attempted suicide in people with co-occurring bipolar and substance use 
disorders: systematic review and meta-analysis. J Affect Disord 2014;167:125-35.

48. Tondo L, Pompili M, Forte A, Baldessarini RJ. Suicide attempts in bipolar disorders: comprehensive review of 101 reports. Acta Psychiatr Scand 2016;133:174-86.

49. Berutti M, Nery FG, Sato R, Scippa A, Kapczinski F, Lafer B. Association between family history of mood disorders and clinical characteristics of bipolar disorder: results from the Brazilian bipolar research network. J Affect Disord 2014;161:104-8.

50. Goldstein BI, Bukstein OG. Comorbid substance use disorders among youth with bipolar disorder: opportunities for early identification and prevention. J Clin Psychiatry 2010;71:348-58.

51. Scavone A, Timmins V, Collins J, Swampillai B, Fonseka TM, Newton D, et al. Dimensional and Categorical Correlates of Substance Use Disorders among Canadian Adolescents with Bipolar Disorder. J Can Acad Child Adolesc Psychiatry 2018;27: 159-66.

52. Lorberg B, Wilens TE, Martelon M, Wong P, Parcell T. Reasons for substance use among adolescents with bipolar disorder. Am J Addict 2010;19:474-80.

53. Goldstein BI, Strober MA, Birmaher B, Axelson DA, EspositoSmythers C, Goldstein TR, et al. Substance use disorders among adolescents with bipolar spectrum disorders. Bipolar Disord 2008;10:469-78.
54. Wilens TE, Biederman J, Adamson JJ, Henin A, Sgambati S, Gignac $\mathrm{M}$, et al. Further evidence of an association between adolescent bipolar disorder with smoking and substance use disorders: a controlled study. Drug Alcohol Depend 2008;95(3):188-98.

55. Nurnberger JI Jr, Foroud T. Genetics of bipolar affective disorder. Curr Psychiatry Rep 2000;2:147-57.

56. Propper L, Ortiz A, Slaney C, Garnham J, Ruzickova M, Calkin CV, et al. Early-onset and very-early-onset bipolar disorder: distinct or similar clinical conditions? Bipolar Disord 2015;17:814-20.

57. Wilens TE, Biederman J, Kwon A, Ditterline J, Forkner P, Moore $\mathrm{H}$, et al. Risk of substance use disorders in adolescents with bipolar disorder. J Am Acad Child Adolesc Psychiatry 2004;43:1380-6.

58. Perlis RH, Miyahara S, Marangell LB, Wisniewski SR, Ostacher M, DelBello MP, et al. Long-term implications of early onset in bipolar disorder: data from the first 1000 participants in the systematic treatment enhancement program for bipolar disorder (STEP-BD). Biol Psychiatry 2004;55:875-81.

59. Stepanova E, Findling RL. Psychopharmacology of Bipolar Disorders in Children and Adolescents. Pediatr Clin North Am 2017;64(6):1209-22.

60. Goldstein BI, Birmaher B, Carlson GA, DelBello MP, Findling RL, Fristad M, CU, et al. The International Society for Bipolar Disorders Task Force report on pediatric bipolar disorder: Knowledge to date and directions for future research. Bipolar Disord 2017;19:524-43. 